\title{
A missiological approach to the involvement of the church in handling school dropouts in South Africa
}

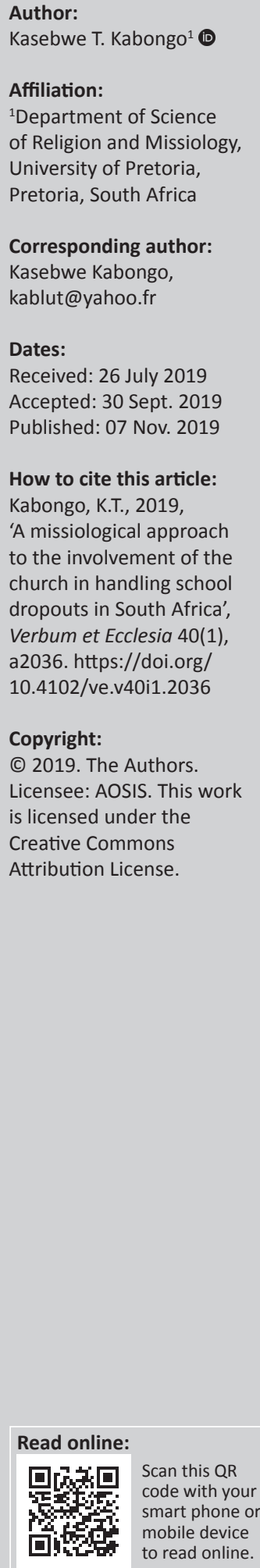

School dropout negatively affects many children living in poor communities of South Africa. Those who drop out of school are usually blamed by people around them for leaving school. However, this article stresses that school dropout can be caused by many factors that are beyond the control of an individual who dropped out. The article is written from the perspective of a person who longs to see the church as a tangible Good News agent in society. He dropped out of school twice in his life, and he is using that painful experience as an experiential learning to connect with school dropouts. He uses the transdisciplinary research method, which deals with the missional and tangible involvement of the church in real issues such as school dropouts to help minimise the scenario of school dropouts. The article stresses that the church can play a prophetic role by educating ordinary people about the causes of school dropouts and proactively help in minimising the same.

Intradisciplinary and/or interdisciplinary implications: This article is located in the field of missiology. It uses the transdisciplinary approach that brings together the disciplines of theology, social work, psychology, public health, education and practitioners, with the aim of finding concrete pathways to minimise school dropouts.

Keywords: church involvement; experiential learning; InnerCHANGE; school dropout; transdisciplinary.

\section{Introduction}

The involvement of the church in societal matters is critical and prophetic. Van Niekerk (2015:1) points out that the 'body of Christ should be involved with those who live' on the margins of our society. Such involvement requires the learning of 'new strategies and new skills that promote a good quality of life' (Van Niekerk 2015:1). Some of the people living on the margins of society are school dropouts. Boyes, Berg and Cluver (2017:195) point out, for instance, that 'higher poverty scores are associated with ... school dropout'.

The author of this article had dropped out of school twice. He was motivated by his negative experience to undertake this research as an experiential learning of what it means to be in solidarity with marginalised people. Katongole (2017:xix) believes that experiential knowledge in theology has the potential to provide a 'decisive and clearest example of hope' Africa needs and which would speak about 'the structures of violence, poverty, and marginalisation into an excess of love'.

This experiential learning is explored collaboratively. The researcher has seen fruitfulness in ministry when working in partnership with other stakeholders. In this article, he ventures into a transdisciplinary method of research, which requires collaboration in result production. Klein (2001:1) points out that the core idea of transdisciplinarity is different academic disciplines working jointly with practitioners to solve a real-world problem'. Such efforts include school dropouts. Similarly, Max-Neef (2005:7) states, 'transdisciplinarity is the result of coordination between all hierarchical levels', which are individual disciplines of knowledge and practitioners. In addition, 'transdiscipline extends its action through several levels of reality' (Max-Neef 2005:15). He stresses:

These levels must be understood as complementary. The transit from one to the other, attaining glimpses from different levels of reality, generates reciprocal enrichment that may facilitate the understanding of complexity. Transdisciplinarity is a different manner of seeing the world, more systemic and more holistic. (Max-Neef 2005:15) 
De Beer and Van Niekerk (2017:237) also acknowledge that issues of our time 'cannot be grasped by one scientific discipline alone'. A comprehensive and holistic solutionseeking need to involve 'other sciences' (De Beer \& Van Niekerk 2017:237). This transdisciplinary approach was used in an asset-based community development framework by bringing together people of one community to share what they have as skills and time, to bless the marginalised such as school dropouts. Green and Haines (2012) define asset-based community development as:

A planned effort to build assets that increase the capacity of residents to improve their quality of life. These assets include several forms of community capital: physical, human, social, financial, environmental, political, and cultural. (p. xi)

This article is a case study that a missional team, InnerCHANGE, engaged in as an active way to minimise school dropout and promote a good quality of life. This missional team is used as an example of what the church could do to participate in helping a community to flourish. Case study research is situated within the broader domain of qualitative social science research. They are in-depth investigations of a single entity or a small number of entities. The entity may be individual, a family group, an institution, a community or other social units' (Polit \& Beck 2008:235). This case study involved 20 children from primary school who were academically struggling, and their parents/ guardians, professionals from different fields of knowledge and tutors. InnerCHANGE started a reading club for these children. A question that guided its action was: How can the church participate as a Good News agent in an issue such as school dropout? The process of answering this question led to results this article shares. It was shaped by an educationalist framework about school dropout.

\section{The framework}

The educationists' (Cabus \& De Witte 2016:3) understanding of the causes of school dropout has motivated this transdisciplinary solution-seeking approach. They state:

\footnotetext{
Multiple factors influence early school leaving. One of them is student attrition, where a student is likely to drop out after one or two retentions in grade. Another factor is teenage pregnancy. Another one is bad health shocks. Another one is the lack of interest in schooling from the child which influences the learner's commitment to the school and peers. Finally, another factor is teaching. (Cabus \& De Witte 2016:3)
}

This understanding of early school leaving led to an exploration of literature to learn about the causes of school dropout from the perspectives of social work, psychology, public health and education. It also led to the sourcing of expertise in the areas of social work, psychology, public health and education within local congregations of the township of Soshanguve. It finally led to the recruiting of emergent community leaders as tutors of the children's reading club. The literature review provided the insights shared below.

\section{Literature review}

Literature review explored existing research on the causes of school dropout in the disciplines of social work, psychology, public health and education. The rationale behind this was not only to get familiar with the existing research but also to discover a research gap that will make this study relevant.

\section{Social work}

Research findings in social works have highlighted four areas as major causes of dropout: family background, poverty, child neglect and violent environments.

- Family background. Rumberger (2012:10) points out that 'family background under the mediation of the school explains most of the variation in educational outcomes'.

- Poverty. Lachman et al. (2002:598) state that 'extreme poverty detracts from school attendance'.

- Child neglect. Neglected children usually have these problems: 'anxiety and low self-esteem, problematic behaviour, educational underachievement, and adverse peer and social relationships' (Casey 2015:410).

- Violent environments. Garbarino and Kostelny (1993:197) stress that children living in violent environments usually suffer from 'post-traumatic stress' that may hurt their academic performance.

\section{Public health}

Research findings in this area have highlighted four major causes of school dropout: health-related problems connected to pregnancy, generic illness or other diseases; smoking; substance abuse; and teenage pregnancy.

- Health-related problems connected to pregnancy, generic illness or other diseases. A report of Centers for Disease Control and Prevention (2016:274) states, 'maternal antenatal alcohol use is one of the leading preventable causes of mental retardation in children'. The damage is significant. It ranges from things like learning difficulties at school or deviant behaviour in social interactions to foetal alcohol syndrome, which is characterised by severe learning disabilities. Van der Wulp et al. (2013:89) stress, 'even low levels of antenatal alcohol exposure could cause adverse neurobehavioral effects in children'.

- Smoking. Norman et al. (2014:216) found out that 'prenatal and postpartum smoking are associated with behavioural and cognitive problems, which have a direct link to academic troubles' amongst other things.

- Substance abuse. According to the American Bureau of Justice (2011:17), 'substance abuse is one of the major causes of class repetition at school'. The substance most abused by pupils is alcohol, followed by cigarettes and marijuana. According to a report released by the American Bureau of Justice (2011:17), 'drugs are known to negatively affect the brain. Alcohol and inhalants are the most brain-damaging drugs of all, as they destroy neurons'. In addition, 'all mood-altering drugs alter the way neurons receive, process and transmit information' (American Bureau of Justice 2011:18). It is done by 
'altering the level of certain neurotransmitters in the synapse, the space between neurons' (American Bureau of Justice 2011:21).

- Teenage pregnancy. According to Modisaotsile (2012:5), a straightforward impediment that causes pupils to drop out is pregnancy. In addition, 'pregnant learners may also experience difficulty in studying because of pregnancyrelated illnesses' (Modisaotsile 2012:5). This new reality can make it difficult for them to strike a good balance between being a mother and a learner, as more time may be spent with the baby than on schoolwork.

\section{Science of education}

Research findings in this area have highlighted four major causes of school dropout: the quality of education given to learners; educators and administrators; political decisions and policies; and managers of the system.

- The quality of education given to learners. Dieltiens and Meny-Gibert (2009:7) stress that 'the primary reason for dropout is the poor quality of education received by learners' in South Africa. Rumberger (2012:14) states, 'several studies suggest that resources influence school dropout rates'. For example, 'the learner/educator ratio affects high school and middle school attendance even after controlling for a host of other individual and contextual factors'. Rumberger (2012:14) also argued that 'the higher the quality of the teachers as perceived by students and learners, the lower the dropout rate'.

- The educators and school administrators. Their competence is key to producing desirable outcomes in the learning of children, as well as their commitment to educationally improve themselves. In South Africa, there is evidence that some 'educators do not have a good enough understanding of subjects they teach' (childrencount. ci.org.za 2016:1).

- Political decisions and policies. In South Africa, Bantu education during apartheid was a sub-standard system that discouraged many black people from staying in school (Kabongo 2015:1). Nkabinde (1997:5) says that 'the term Bantu referred to blacks'. Therefore, Bantu Education alluded to a 'type of education designed for black people only'. Its aim was twofold: 'to provide a separate and unequal education to different races of South Africa and to inculcate in Blacks a sense of inferiority' (Nkabinde (1997:9). Most of the South African educators are graduates of Bantu education who, even with their best intentions, are unable to adequately teach children. Taylor (2012:7) believes that 'many teachers are just too badly educated themselves'. Taylor (2012:7), who until 2015 was the Director of the 'National Education Evaluation and Development Unit', wrote in 2012 a comprehensive report of the stage of our education system. He had concluded that many public schools' foundation phase educators 'lacked all three aspects needed' for quality teaching: 'knowledge of the subject; knowledge of the curriculum; and knowledge of how to teach the subject'.
He went into details to say these educators are both unable 'to follow the prescripts of the official curriculum', and 'unaware of what these are'.

- Managers of the system. Jansen (2011:107-108) remarks that teacher training does not address the knowledge problem. According to him (Jansen 2011):

$[D]$ ifferent kinds of knowledge need to be considered: knowledge of the subject matter (content knowledge); knowledge of teaching (pedagogy); knowledge of learners (psychology); knowledge about knowledge (epistemology); knowledge of communities from which the learners come (anthropology, sociology of learning); knowledge of classroom organisation and discipline (managerial knowledge); and more. (pp. 107-108)

\section{Psychology}

Research findings in this area highlighted three major causes: a child psychological condition, learning disabilities and children under the care of mentally disturbed parents or guardians.

- A child psychological condition. Rumberger (2012:14) states, 'child's psychological condition can impede his/her ability to cope academically and could lead to school dropout'.

- Learning disabilities. The South African Department of Basic Education points out that 'learning disability can cause children to dislike school, act up at school or do things to distract from the fact that they're not doing well' (education.gov.za 2016).

- Children under the care of mentally disturbed parents or guardians. Such children will most likely 'develop mental problems potentially compromising their academic carrier' (Wadsby et al. 2007:17).

The above-mentioned findings were put together having in mind the alarming reality of school dropout in South Africa, especially in communities where poverty is prevalent, such as the township of Soshanguve. In 2017, Business Tech (businesstech.co.za 2017) published a table showing the reality of school dropout throughout South Africa, per province (Table 1).

The economist Spaull (2012:8) shed more graphic details, that nationally, of the learners still being in school, $27 \%$ of them were 'functionally illiterate'. Moreover, he stresses

TABLE 1: Reality of school dropout in South Africa.

\begin{tabular}{lcccccc}
\hline Province & $\begin{array}{c}\text { Grade 10 } \\
(\mathbf{2 0 1 4})\end{array}$ & $\begin{array}{c}\text { Grade 12 } \\
(\mathbf{2 0 1 6 )}\end{array}$ & $\begin{array}{c}\text { Dropout } \\
\text { rate (\%) }\end{array}$ & $\begin{array}{c}\text { Grade 12 } \\
\text { pass }\end{array}$ & $\begin{array}{c}\text { Pass } \\
\text { rate (\%) }\end{array}$ & $\begin{array}{c}\text { 'True' pass } \\
\text { rate (\%) }\end{array}$ \\
\hline Northern Cape & 22034 & 10041 & 54.4 & 7902 & 78.7 & 35.9 \\
North West & 67734 & 32045 & 52.7 & 26448 & 82.5 & 39.0 \\
Free State & 55293 & 26786 & 51.6 & 23629 & 88.2 & 42.7 \\
Eastern Cape & 154220 & 82902 & 46.2 & 49768 & 59.3 & 31.9 \\
Limpopo & 189170 & 101807 & 46.2 & 63595 & 62.5 & 33.6 \\
KwaZulu-Natal & 264816 & 147648 & 44.2 & 98032 & 66.4 & 37.0 \\
Mpumalanga & 94528 & 54251 & 42.6 & 41801 & 77.1 & 44.2 \\
Gauteng & 174471 & 103829 & 40.5 & 88381 & 85.1 & 50.7 \\
Western Cape & 75791 & 50869 & 32.9 & 43716 & 86.0 & 57.7 \\
South Africa & 1100877 & 610178 & 44.6 & 442672 & 72.5 & 40.2 \\
\hline
\end{tabular}

Source: Business Tech, 2017, viewed 31 December 2017, from https://businesstech.co.za/ news/general/149291/shocking-drop-out-rates-where-in-south-africa-the-fewest-kidsmake-it-to-matric/. 
that this national average hides the reality of learners from poor communities such as Soshanguve. The reason is that (Spaull 2012):

South Africa is still a tale of two schools: one which is functional, wealthy, and able to educate students; with the other being poor, dysfunctional, and unable to equip students. (p. 14)

The majority of learners are functionally literate in wellresourced schools as opposed to the majority of learners being functionally illiterate in schools located in poor communities (Spaull 2012:14).

\section{Research gap}

In the literature review, I did not come across a transdisciplinary study involving social work, psychology, public health and science of education to engage the issue of school dropout in a particular context. This research in a small way intends to address this gap. The process of that led to asking professional volunteers involved in this research about their experiential knowledge of the causes of school dropout.

\section{Insights from professional volunteers}

Professional volunteers affirmed the research findings from the above-mentioned literature review. They also brought up new and unique insights that were invaluable. Below are new insights provided by them.

\section{Social worker}

According to the social worker volunteer involved in this research, poor parenting, peer pressure, under-resourced schools, ineffective school programmes, lack of behaviour programmes for children who come from dysfunctional families and crime-infested environments such as the township could lead to school dropout. And, an early referral to vocational schools and the capacitation of schools with proper skills could be a good remedy to school dropout.

\section{Nurse}

According to the nurse volunteer involved in this research, eyesight and hearing problems could make it difficult for a child to hear what is going on in the classroom. A poor diet could also negatively affect a child's attention span in the classroom. Abortion attempts, especially during the third trimester, could lead to brain damage and therefore make the child struggle to thrive in school.

\section{Educator volunteer}

According to the educator volunteer involved in this research, the language barrier could be a cause of school dropout. She also added the South African government's wrong priorities of constant curriculum change and policy-making over daily teaching and learning conditions. According to her, daily teaching and learning conditions should take priority over curriculum change and frequent policy-making. She finally alluded to the attention span of children as a cause of school dropout. A remedy could be for the government to establish functional partnerships with educators, communities and institutions of higher learning.

\section{Psychologist volunteer}

According to the psychologist volunteer involved in this research, the urban setting realities of dysfunctional families, overcrowded and under-resourced schools traumatise many children and make them susceptible to dropping out of school. And a good remedy could be for our education system to balance its focus between what and how children learn.

All the above-mentioned insights from professional volunteers were taken into consideration and implemented in our reading club. The latter was initiated by InnerCHANGE to help improve the reading ability of children from grade $\mathrm{R}$ to grade 4 . Each grade had four learners and one tutor.

\section{Implementation}

This section covers the fieldwork this research undertook. The fieldwork was inspired by the words of Karl Marx as quoted in Thuma foundation (2017:1) that, 'philosophers have hitherto interpreted the world in various ways, the point is to change it'. The research endeavoured to explore an alternative way of teaching and the role of the church to concretely bring healing through the affirmation that God created all human beings in his likeness. It was also inspired by Albert Einstein's quote: 'Everybody is a genius. However, if you judge a fish by its ability to climb a tree, it will live its whole life believing that it is stupid' (quoteinvestigator.com. 2019:1).

This section also brings together the transdisciplinary solutionseeking this research undertook. It involved different stakeholders in solution-seeking. One of the stakeholders was the reading club children's parents or guardians. The tutors and I visited the latter at their homes. We used a comprehensive questionnaire covering the social circumstances, health, history, psychological assessment and learning abilities of a child assessed during our visits. From interviewing the parents or guardians of children, we found out that 18 out of 20 of our children ( $90 \%$ ) were born from unplanned pregnancies. Also, six out of 20 mothers (30\%) admitted to using alcohol or smoking during pregnancy. Also, 16 out of 20 parents or guardians (90\%) admitted to having sort of medical treatment during pregnancy. Also, 11 out of $20(55 \%)$ mothers had pre-term babies, who are known to have a hard time coping well in school. We learnt from parents or guardians that six out of $20(30 \%)$ of our children were below par in their motor development compared with their peers. This made more sense after we came to know that some of our children were born pre-term and many more take medications daily. Also, only six $(30 \%)$ of our children like school. Of those who did not like going to school, the causes were associated with some form of bullying. There was one case of corporal punishment at school and two cases of educators swearing at children. We also found out that $12(60 \%)$ parents or guardians felt their child had a good 
relationship with their educator, while others did not. We also learnt from parents or guardians that only two $(10 \%)$ self-initiated doing homework. This is understandable because of the children's age and lack of understanding of the importance of doing homework. This reality is also connected to the insights from both our social worker and educator volunteers stressing that there is no culture of learning in many urban poor communities of South Africa and that learning starts and stops at school. We also learnt that only nine $(45 \%)$ children wake up in the morning and are excited about going to school. The other 11 (55\%) have to be dragged out of bed or the house; others have to be bribed with some money to go to school. From this awareness, I was left wondering if this may be a schooling system we needed to interrogate: all schools start in the morning. I know that some people function better in the afternoon or at night than in the morning. Could some of our children academically perform better in the afternoon than in the morning? We finally learnt that corporal punishment at home is still a common practice. Of our children, nine (45\%) were corporally punished at home.

The analysis of collected data inspired seeking solutions to the difficulty that our children experienced in reading. From the beginning of this programme, the goal in mind was to improve the children's reading fluency, get to the best level possible and help them improve their understanding of the content they read. With the advice of our educator volunteer, we used the 'Hasbrouck-Tindal oral reading fluency chart' (readnaturally.com 2017:1), which is a tool that helped us 'rate the reading fluency of' all our children. This tool helped us to build a fluency programme and expectation for all the grades involved. Our basic benchmark was to help a child read fluently and aloud the assigned books of his or her grade. We had learnt that a child's 'ability to read aloud with speed, accuracy and expression' was foundational and essential in the cultivation of an appetite for reading (Spaull 2016:27). In the assessment of the effectiveness of our programme, we took into consideration 'the 5 components for good reading accomplishments' (Spaull 2016):

'Phonemic awareness': We made sure that children could 'hear and identify' phonics in their reading.

'Alphabetic principle': We helped the children 'understand that words are made up of letters that represent segments of the speech'. We also helped them 'understand the relationship between letters and phonics.

'Vocabulary': We were creative in our use of words that were meaningful to the children.

'Comprehension': We led them to draw meaning from reading a text and share it.

'Fluency': We helped the children read in a way that 'connected the text quickly, accurately and with meaningful expressions'. (p. 31)

The research team that comprised 10 people (five tutors, four professionals and me) gathered every quarter as a focus group to reflect on our actions. We gathered four times throughout this research. We started by asking this question: How can our learning environment be attractive to children?
We resolved to create a fun environment and be holistic in our teaching in balancing the right- and left-brain styles of learning and teaching. We also experimented with different discipline methods during our activity times, which improved our learning environment. The results of the implementation of these different elements led to the improvement of $50 \%$ of our children in their ability to read from the first quarter. These results led to another question: How can we get to $100 \%$ improvement? The answer to this question was to learn from schools in collaborating with the children's educators, upskilling our tutors and using some professional skills to assess struggling children.

Our task was now to maintain what worked for the 10 of us and start figuring out something that could work for those who were still struggling. We took our findings to the children's schools, shared them with their educators and started building a relationship with the children's schools. We exposed our tutors to some formal early childhood education training so that they can learn various methods and approaches to teaching.

Our social worker and psychologist volunteers committed to volunteer more of their time to help with the assessment of the individual needs of the children. They did some assessment of the children through the images, drawings, collages and sport. The step-by-step process of this assessment was a diagnosis of children's attention span. The steps of the assessment were the following (Kabongo 2017):

Give a drawing or collage task to a child and give him/her 10 minutes to finish it.

After 10 minutes, check if the task is completed.

If the task is completed, have the child take a break and give another 10-minute creative art task and check if it is completed within the allocated time.

If a task is not completed, have the child take a break. Afterwards, give him/her again a 10-minute task for 12 minutes: five minutes work, two minutes break and five minutes work again.

If the task is completed then, we gave this child many breaks (after every five minutes, two minutes break) during our 80 minutes creative and reading times. (pp. 10-11)

This assessment was done against the backdrop of Mahone and Schneider's (2012:1) findings, that 'early developmental differences involving attentional control in children are considered to arise from a variety of influences', including genetic, temperamental and environmental factors. And the strongest early predictors of attention problems include premature birth, low birth weight, prenatal tobacco exposure, non-intact family, young maternal age, paternal history of antisocial behaviour and maternal depression. Our task in the next quarter was going to examine the attention span of our struggling children in their acquisition of knowledge. The result of this change of strategy led to an improvement of $30 \%$ more.

We were now at $80 \%$ improvement of the group at the end of the third quarter. Parents or guardians and educators also 
concurred with this assessment based on what they saw at home and in the classroom. A parent of one of our children saw the good fruit of our labour and took the initiative to connect InnerCHANGE to a funding organisation she knew. We made an application, which was approved, and we got some much-needed funding to increase our staff capacity, our art materials and buy more stationery. We were very encouraged in seeing a kind of partnership we have always desired with our community. We still needed to figure out how to help four children out of the 20 we had, to improve their ability to read.

For the remaining four, we recommended vocational schools based on our assessment. The four children had noticeable talents. However, these talents were not good enough for them to thrive in our reading club or a normal public school. These talents could be an asset to the children as well as our society if they were nurtured in appropriate institutions such as vocational schools.

The process of these results captured the transdisciplinary nature of this research. We worked as a group with our different strengths and skills that led to the results shared. Transdiscipline catalysed a synergetic collaboration between knowledge acquired in the academia (professional volunteers' input) and experiential knowledge (tutors and a pastor), which led to life-affirming actions that led to judging a fish by its ability to swim, not to climb a tree'. As members of the body of Christ, the metaphor of different members of a human body playing specific roles (1 Cor 12:18-23) served as a reminder of why we were doing and what we were doing. We also armed ourselves with the hope that comes from the biblical truth that states that God created every human being in his likeness (Genesis 1:27) and with at least one talent (Matthew 25:14-30). Our faith helped us interact with children with expectation. There is an expectation that we will discover a genius in each of the children we had in our programme. We were humbled to see this expectation come true for most of the children.

\section{End of the year assessment}

By the end of the school year, our team was pleased and humbled to see 16 out of 20 children significantly improving their ability to read and understand the content of their reading. We were also saddened to admit that we could not help four of our children to improve their reading ability, but we were able to help catch the genius in them when it came to hands-on things.

As a team, we also understood that to cultivate an appetite for reading and learning in our children, we need to be lifelong learners. All our tutors and I took Early Childhood Education courses and learnt how to teach in home languages such as Sepedi, Setsonga and Isizulu. We are all members of a local library and regularly visited it to get books to read.

The education alternative we discovered after a year of experiments was one based on the search for a child talent or energy-giving activity. We 'tailor-made' our reading curriculum based on these talents and areas of interest. Such an approach changed a lot of our children's attitude towards learning. We saw many of them move from dragging their feet to being punctual for classes.

\section{Insight for the church}

Through a practical initiative, such as the reading club, our missional team drew lessons for future ministry initiatives by regularly reflecting on decisions we made or suggestions we came up with. This article frames the learnt lessons in the form of a guideline for a local congregation desiring to be involved in community-based service. The first element has to do with setting the tone (Kabongo 2018):

Be yourself: Start an initiative that is meaningful to you or that is dear to your heart.

Learn to win people around you through your exemplary influence and a clear expression of your passion. Many people are open to serve. They get their inspiration from observing a person or a group of people. Recruit and build a team with people who are passionate to serve. One of the best ways to attract outstanding people on your team is to showcase the outstanding people that are already part of your team.

Find a venue people will come to.

Put together an infrastructure that is welcoming to your target group. Think about swings, for example, and an adventure course for children.

Seek to build a partnership with key stakeholders with whom you have a shared passion and commitment to a cause from the very beginning of the process.

Make sure that having fun is a significant part of your team dynamic as well as your interaction with beneficiaries. Build a resource package to create a fun environment. Think about songs, games, stories the beneficiaries could enjoy.

Be constructive in your criticism. Be open to suggestions about ways to improve the program. Debrief and reflect on your actions and experiences regularly. Listen to stakeholders' hopes and expectations and communicate yours in a compelling and persuasive manner.

Train team members regularly about the 'how-to' of things and diversify trainers. Educate yourselves on different styles of learning and diversify learning environments.

Create a healthy and sustainable incentive system for both teammates and beneficiaries.

Work on a tailor-made curriculum and learn to think outside the box. (p. 2)

The second element has to do with vision casting (Kabongo 2018):

It is important to regularly remind teammates of the aim and the vision behind your initiative.

It is also important to remain open to new ideas coming from your team and the beneficiaries.

In a community-based project, it is critical to give ownership of the initiative to the community itself.

Build your initiative philosophy in a transferable format. It is important that the passing of the baton is possible and smooth. 
Also, we found it important to transfer the content of our aim in a user-friendly format such as songs, drama, recitation and dance for our children. (p. 3)

The third element has to do with identity and reputation (Kabongo 2018):

There should be integrity between the vision of your initiative and your actions.

Catalyse a healthy team dynamic that would foster trust amongst members and between the team and community members.

Regularly reach out to stakeholders to deepen the collective ownership of the initiative. (p. 3)

The fourth element has to do with communication (Kabongo 2018):

State to your team and people interested in your programme your identity and the aim of the program. For example, it was very important for our missional team to state the fact that we are a Christian organisation and through the reading club, we were learning to be Good News agents in loving our children in a tangible way like John 13:33-35 and we were also going to disciple these children.

Use different mediums of communication to keep the initial vision alive and fresh to teammates, beneficiaries and all the stakeholders involved. (p. 3)

The fifth element has to do with disputes and conflicts (Kabongo 2018):

Conflict will arise when people work together. Keep a short account of those conflicts. Be objective in the resolution of them in bringing into the discussion all the parties involved.

Disputes brought to your attention should be handled objectively and with sensitivity. (p. 4)

The sixth and last element has to do with violations:

From the beginning of the initiative, state the consequences of violations upfront to teammates and all stakeholders involved. It is then critical to be proactive and consistent in enforcing them (Ligaya Tichy 2013:2-6).

\section{Reflection}

The outcome of our reading club was a direct implementation of the biblical message of loving others sacrificially (Lk 9:23-26) in seeking the welfare of an urban community (Jr 29:7) and in involving a community to build and actively seek answers to its own prayers (Neh 2:18). Through this reading club, we were not only able to showcase the children's abilities and genius but also able to confront the prejudice that some parents or guardians, as well as educators, seem to have towards children who are not doing well in school. In this regard, we were able, in a small way, to reconcile children to their families, and educators to their learners.

The reading club was also a discipleship platform. We did creative bible studies, which the children replicated and transferred to their homes. As a result, we did not only see children knowing Christ but also saw parents or guardians coming to Christ and wanting to be good news to others around them in tangible ways.

We were also able to see how the church could make a unique contribution to society through community development work: to put skill and calling in a symbiotic relationship. Skills played a key role in helping children improve their reading ability. Calling has to do with the passion and commitment of our research partners to be good news, loving and compassionate neighbours. In our South African context, skill seems to be the primary reason why someone is hired to do a certain job. However, in many instances, we see skilled people being at work without working. In this study, calling is understood as a faithful response to God's instruction to his children to be a conduit of his blessing to the whole of humanity (Gn 12:3). Wright (2010) says it nicely in this statement:

The bible is passionately concerned about what kind of people they are who claim to be the people of God. If our mission is to share the good news, we need to be good news people. If we preach a gospel of transformation, we need to show some evidence of what transformation looks like. So there is a range of questions we need to ask about the whole church that has to do with things like integrity, justice, unity and inclusion, and Christlikeness. The biblical word is 'holiness', and it is as much a part of our missional identity as of our personal sanctification. (pp. 29-30)

Through this reading club, we experienced what it means to be good news people or agents in a tangible way. We experienced a good outcome when there was synergy between the knowledge of 'how to' and a heartfelt desire to be a conduit of God's blessing to others. The church could encourage its members to approach their professional tasks as a calling. Such an approach has the potential to improve service delivery and the birthing of good news stories in different spheres of our society (Wright 2010:29-30). Shane Claireborne (Perkins 2014) once said:

If you want to know what someone believes, watch how they live. Each one of us is a potential living epistle. Our lives and actions shout what we believe, sometimes even louder than our words. So often, people cannot even hear our words past the noise of our lives. (p. 9)

It is important for fellow Christians, 'to become a proclamation of the good news of the gospel' (Perkins 2014:10). Billy Graham (quoted by Otto 2014:x) said it nicely this way: 'It's the holy spirit['s] job to convict, God's job to judge, and our job as human beings to love others'.

Local churches and the community put hands together to find solutions. The agency from grassroots people is the best way to bring sustainable solutions to issues such as school dropout. Castellanos (2014:13-14) points out that like in the days of Nehemiah, it will take a group of pioneers who would use their acquired skills and time to be missional in building their community in tangible ways. They will be the catalysts of the emergence of the Shalom of God, which will begin to emerge in every environment they live in. Perkins (1993:18) stresses that the church should communicate the reconciling love of God into the love of our marginalised neighbours. 
At the end of this transdisciplinary solution-seeking, we wondered what it would look like if the government entered into a partnership with universities and colleges, so that students from different disciplines could intern at public schools to support the already overburdened educators. Public universities and colleges could fulfil their goal to participate in the public good (De Beer \& Van Niekerk 2017:216-217) and the government will get some muchneeded capacity to serve school children better.

\section{Conclusion}

Through this transdisciplinary approach, this article demonstrated a role the church could play in improving the quality of life of people and catalyse the healing of a community by itself. Research findings from social work, public health, education and psychology enlightened our understanding of causes of school dropout. The experiential knowledge of our professional volunteers also made us aware of the complex causes of school dropout. Community members of Soshanguve were also involved in this research as tutors and the parents/ guardians of the children. The collaboration between different disciplines of knowledge and practitioners led to life-affirming actions that resulted in the majority of the children learning how to read. The results of the reading club highlighted the need for the church to be an active participant in community development, so that the people living on the margins of society could be brought to the centre where they will flourish by functioning maximally according to their ability.

\section{Acknowledgements}

This article is based on my doctoral thesis submitted in August 2018 at the University of Pretoria.

\section{Competing interests}

The author has declared that no competing interests exist.

\section{Authors' contributions}

I declare that I am the sole author of this research article.

\section{Ethical considerations}

This article followed all ethical standards for research without direct contact with human or animal subjects.

\section{Funding information}

This research received no specific grant from any funding agency in the public, commercial or not-for-profit sectors.

\section{Data availability statement}

Data sharing is not applicable to this article as no new data were created or analysed in this study.

\section{Disclaimer}

The views and opinions expressed in this article are those of the author and do not necessarily reflect the official policy or position of any affiliated agency of the author.

\section{References}

American Bureau of Justice, 2011, viewed 19 December 2017, from www.education org.za/.

Boyes, M.E., Berg, V. \& Cluver, L.D., 2017, 'Poverty moderates the association between gender and school dropout in South African adolescents', Vulnerable Children and Youth Studies 12(3), 195-206. https://doi.org/10.1080/17450128.2017. 1308613

Business Tech, 2017, viewed 31 December 2017, from https://businesstech.co.za/ news/general/149291/shocking-drop-out-rates-where-in-south-africa-thefewest-kids-make-it-to-matric/.

Cabus, S.J. \& De Witte, K., 2016, 'Why do students leave education early? Theory and evidence of high school dropout rates', Journal of Forecasting 35(8), 690-702. https://doi.org/10.1002/for.2394

Casey, B., 2015. 'Child neglect', in J.D. Wright (ed.), International Encyclopedia of the Social \& Behavioral Sciences, 2nd edn., vol. 3, pp. 410-416. Elsevier, Saint Louis.

Castellanos, N., 2014, When the cross meets the street. What happens to the neighborhood when God is at the center, IVP Books, Downers Grove, IL.

Centers for Disease Control and Prevention, 2016, viewed 05 June 2016, from www. education.gov.za.

Childrencount, 2016, viewed 21 February 2016, from http://www.childrencount.org. $\mathrm{za} /$ indicator. $\mathrm{php}$ ?id $=6$ \& indicator $=44$

De Beer, S.F. \& Van Niekerk, A.S., 2017, 'Transforming curricula into the next century: Doing theology collaboratively with local communities', in D. Veldman (ed.), Theology at the University of Pretoria - 100 years: (1917-2017) Past, present and future, Verbum et Ecclesia 38(4), a1683. https://doi.org/10.4102/ve.v38i4.1683

Dieltiens, V. \& Meny-Gibert, S., 2009, School drop-out: Poverty and patterns of exclusion, viewed 01 March 2016, from http://www.ci.org.za/depts/ci/pubs/pdf/ general/gauge2008/part_two/exclusion.pdf.

Einstein, A., 2019, viewed 25 July 2019, from https://quoteinvestigator.com/2013/04/ 06/fish-climb/.

Garbarino, J. \& Kostelny, K 1993, 'Neighborhood and community influences on parenting', in T. Luster \& L. Okgaki (eds.), Parenting: An Ecological Perspective, pp. 203-226, Lawrence Erlbaum Associates publishers, Hillsdale, New Jersey.

Green, G.P. \& Haines, A., 2012, Asset building \& community development, 3rd edn., Sage, Los Angeles, CA.

Jansen, J., 2013a, 'Percy Baneshik Memorial Lecture to the English Academy of South Africa', in R. Chetty (ed.), Journal of English Studies 31(1), Taylor \& Francis, Milton park, Oxfordshire.

Jansen, J., 2013b, viewed 09 December 2017, from https://mg.co.za/article/2013-10 04-wrest-power-from-english-tyranny.

Kabongo, K.T.L., 2015, 'Ministry with poor community: A missional appraisal of the InnerCHANGE tutoring ministry in Soshanguve', Masters dissertation, University of Pretoria.

Kabongo, K.T.L., 2017, 'Notes taken during conversations with professional volunteers', unpublished notes, CRM hub: Anaheim.

Kabongo, K.T.L., 2018, 'How to run InnerCHANGE reading clubs', unpublished instructions, CRM hub: Anaheim.

Katongole, E., 2017, Born from lament. The theology and politics of hope in Africa, William B. Eerdmans, Grand Rapids, MI.

Klein, J.T., 2001, 'The discourse of transdisciplinarity: An expanding global field', in R. Haberli, M. Welti, A. Bill, R.W. Scholz, W. Grossenbacher-Mansuy \& J.T. Klein (eds.), Transdisciplinarity: Joint problem solving among science, technology, and society, pp. 35-44, Birkhäuser, Basel.

Lachman, P., Poblete, X. \& Ebigbo, P.O., 2002, 'The effect of poverty on child protection in Africa', Child Abuse \& Neglect 26(2002), 587-617.

Ligaya Tichy, 2013, viewed 04 April 2018, from https://www.youtube.com/watch?v= RnmRWsLCYTA

Mahone, E.M. \& Schneider, H.E., 2012, 'Assessment of attention in preschoolers', Neuropsychology Review 22(4), 361-383. https://doi.org/10.1007/s11065-012 9217-y

Max-Neef, M.A., 2005, 'Commentary foundations of transdisciplinarity', Ecological Economics 53(2005), 5-16, viewed 23 April 2016, from www.sciencedirect.com.

Modisaotsile, B.M., 2012, The failing standard of basic education in South Africa, viewed 31 January 2017, from http://www.ai.org.za/wp-content/uploads/downloads/2012/03/ No.-72.The-Failing-Standard-of-Basic-Education-in-South-Africa1.pdf.

Nkabinde, Z.P., 1997, An analysis of educational challenges in the new South Africa, University Press of America, Lanham, MD.

Norman, A., Constantine, N.A., Slater, J.K. \& Carroll, J.A., 2014, 'Smoking cessation, maintenance, and relapse experiences among pregnant and postpartum adolescents: A qualitative analysis', Journal of Adolescent Health 55(2014) 216-221. https://doi.org/10.1016/j.jadohealth.2013.12.027

Otto, T., 2014, Oriented to faith. Transforming the conflict over gay relationships, Cascade Books, Eugene, OR.

Perkins, J.M., 1993, Beyond charity. The call to Christian community development, Baker Books, Grand Rapids, MI.

Perkins, J.M., 2014, Let Justice roll down, Baker Books, Grand Rapids, MI.

Polit, D.F. \& Beck, C.T., 2008, Nursing research. Generating and assessing evidence for nursing practice, 8th edn., Lippincott Williams \& Wilkins, Hong Kong. 
Readnaturally, 2017, viewed 17 January 2017, from https://www.readnaturally.com/ knowledgebase/how-to/9/59.

Rumberger, R.W., 2012, 'Student engagement, peer social capital, and school dropout among Mexican American and Non-Latino white students', Sociology of Education 81(April), 109-139. https://doi.org/10.1177/0038040 70808100201

Spaull, N., 2012, Poverty \& privilege: Primary school inequality in South Africa, Stellenbosch economic working papers 13/12, Stellenbosch University, Cape Town.

Spaull, N., 2016, viewed 03 February 2018, from http://resep.sun.ac.za/wp-content/ uploads/2016/05/RESEP-Policy-Briefs_Nic_Spaull-EMAIL.pdf.

Taylor, N., 2012, Needu National Report, viewed from www.shineliteracy.org.za/wpcontent/uploads/2015/11/NEEDU-Report.pdf.

Thuma Foundation, 2017, viewed 06 June 2017, from www.Thumafoundation.org.
Van der Wulp, N.Y., Hoving, C. \& De Vries, H., 2013, 'A qualitative investigation of alcohol use advice during pregnancy: Experiences of Dutch midwives, pregnant women and their partners', Midwifery 29(11), 89-98. https://doi.org/10.1016/j. midw.2012 11.014

Van Niekerk, A.S., 2015, Mission in practice, Module (GSW310/314) given at the Faculty of Theology and Religion, University of Pretoria, Pretoria.

Van Wyk, C., 2007, We write what we like. Celebrating Steve Biko, Wits University, Johannesburg.

Wadsby, M. , Svedin, C.G. \& Sydsjo, G., 2007, 'Children of mothers at psychosocial risk growing up: A follow up at the age of 16 ', Journal of Adolescence 30(2007), 147-164, Science direct. https://doi.org/10.1016/j.adolescence.2006.08.001

Wright, C.J.H., 2010, The mission of God's people: A biblical theology of the church's mission. Biblical theology of life, Zondervan, Grand Rapids, MI. 